https://helda.helsinki.fi

Effects of Acidification on the Mobilization of Cadmium and Mercury from Soils

Lodenius, $\mathrm{M}$.

Springer-Verlag New York

1989

Lodenius, M. and Autio S. 1989. Effects of Acidification on the Mobilization of Cadmium and Mercury from Soils. Archives of Environmental Contamination and Toxicology 18: 261-267.

http://hdl.handle.net/1975/191

Downloaded from Helda, University of Helsinki institutional repository.

This is an electronic reprint of the original article.

This reprint may differ from the original in pagination and typographic detail.

Please cite the original version. 
Arch. Environ. Contam. Toxicol. 18, 261-267 (1989)

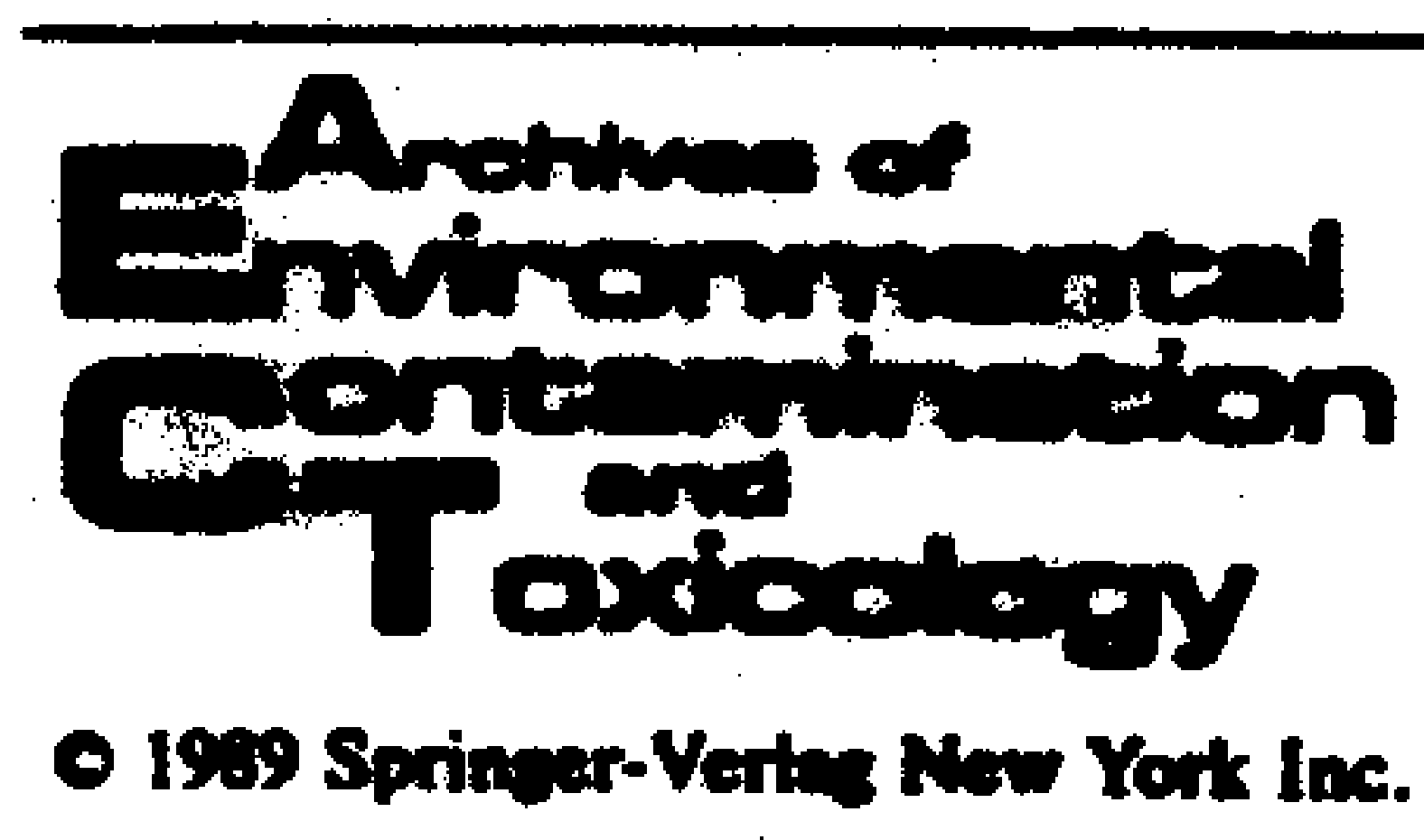

\title{
Effects of Acidification on the Mobilization of Cadmium and Mercury from Soils
}

\author{
Martin Lodenius and Sari Autio \\ Department of Environmental Conservation, University of Helsinki, SF-00710 Helsinki, Finland
}

\begin{abstract}
The sorption and mobility of cadmium and mercury in two different soils were studied in the laboratory using lysimeter columns and tracer techniques. Both metals were sorbed strongly to the peat soil. The effects of four eluents with different acidity were studied at two temperatures. Cadmium was released at low pH-values. A strong leaching was also observed after treatment with a neutral salt solution with an ionic strength corresponding to a soil solution.

For mercury, the difference in leaching after different treatments and between the two temperatures were smaller. The leaching of mercury was, however, slightly enhanced by decreasing the temperature.
\end{abstract}

The spreading of acid air pollutants causes severe effects on terrestrial ecosystems both directly on and through the soil. Among other effects, it has been assumed that the acidification of the soil environment enhances the solubility of heavy metals.

It is well known that the solubility of cadmium increases with decreasing $\mathrm{pH}$. On the contrary, the sorption of mercury to soil organic matter increases with decreasing pH (Lodenius et al. 1983). The influence of soil properties on the sorption of these metals are poorly known.

\section{Material and Methods}

The lysimeter columns used in the experiments were made of polyethylene (Lodenius et al. 1983) and they were filled with sand or peat (Table 1). ${ }^{200} \mathrm{Hg}$-acetate $\left(20 \mu \mathrm{Ci}=740 \mathrm{kBq} ; \mathrm{T}_{n}=\right.$ $47 \mathrm{~d})$ and ${ }^{105} \mathrm{Cd}-\mathrm{chloride}\left(10 \mu \mathrm{Ci}=370 \mathrm{kBq} ; \mathrm{T}_{\nu_{2}}=453 \mathrm{~d}\right)$ were mixed with inactive carriers and added to the top of the columns. Four different eluents were used: distilled water,

artificial acid rain, $\mathrm{pH} 5.4\left(\mathrm{H}_{2} \mathrm{SO}_{4}\right.$ and $\mathrm{HNO}_{3}$; corresponding to the precipitation in northern Finland)

artificial acid rain, $\mathrm{pH} 3.6\left(\mathrm{H}_{2} \mathrm{SO}_{4}\right.$ and $\mathrm{HNO}_{3}$; corresponding to the precipitation in Central Europe)

a salt solution, $\mathrm{pH} 7.0\left(\mathrm{Ca}^{++}, \mathrm{Na}^{+}, \mathrm{NO}_{3}^{-}\right.$and $\mathrm{SO}_{4}^{--}-$-ions; corresponding to soil solution.

The amount of eluent, $9 \times 171 \mathrm{ml}$, corresponds roughly to the annual precipitation in Finland. The experiment was performed at two temperatures: $+20^{\circ} \mathrm{C}$ and $+5^{\circ} \mathrm{C}$. The length of the experiment was 73 days and samples of the leachates were collected nine times during the experiment. Volume, absorbance at 270 $\mathrm{nm}, \mathrm{pH}$, and the activity values of $\mathrm{Cd}$ and $\mathrm{Hg}$ were measured.

The carbon and nitrogen contents of the soil samples were analyzed, using a Hewlett-Packard 185B $\mathrm{C}$ - $\mathrm{N}$-analyzer. The isotope activities were measured by a two channel gamma counter (Wallac Ultrogamma) directly from the leachates and after diluting the soil samples in strong acid $\left(\mathrm{H}_{2} \mathrm{SO}_{4}+\mathrm{HNO}_{3}\right)$.

\section{Results}

\section{Leachates}

Due to a larger evaporation, the volumes of the leachates were smaller in $+20^{\circ} \mathrm{C}$ than in $+5^{\circ} \mathrm{C}$ (Table 2). The amounts leached out from peat were somewhat higher than those leached out from sand. No significant differences were detected between the amounts of leachates from different treatments.

The leachates from peat were usually more acid than those from sand (Table 3). A decrease in temperature caused an acidification of the leachates. The pH-values of the leachates rose slightly during the experiment. The addition of a neutral salt solution caused a strong acidification, probably due to ion exchange in both peat and sand. The pH-value increased in the following order: salt $>$ pH $3.6>$ water > pH 5.4.

With the exception of the leachates from the salt treatment the humus content (color) was higher in 
Table 1. Properties of the soils used in the experiments

\begin{tabular}{lllll}
\hline & $\mathrm{pH}\left(\mathrm{CaCl}_{2}\right)$ & $\mathrm{C} \%$ & $\mathrm{~N} \%$ & $\mathrm{E}_{\sqrt{4}} / \mathrm{E}_{6}$ \\
\hline Peat & 3.6 & 44 & 1.4 & 12 \\
Sand & 4.5 & 0.47 & 0 & 6.8
\end{tabular}

- Rate of absorbances at 465 and $665 \mathrm{~nm}$ in $0.05 \mathrm{~N} \mathrm{NaHCO}_{3}$ leachate

Table 2. Cumulative leachate volumes $(\mathrm{ml})$ after 24 and 73 days

\begin{tabular}{|c|c|c|c|c|c|}
\hline \multirow{2}{*}{\multicolumn{2}{|c|}{ Treatment }} & \multicolumn{2}{|c|}{$\begin{array}{l}+20^{\circ} \mathrm{C} \\
\text { Days }\end{array}$} & \multicolumn{2}{|c|}{$+5^{\circ} \mathrm{C}$} \\
\hline & & 24 & 73 & 24 & 73 \\
\hline \multirow[t]{4}{*}{ Sand } & pH 3.6 & 217 & 815 & 460 & 1290 \\
\hline & pH 5.4 & 145 & 698 & 460 & 1300 \\
\hline & Salt & 153 & 696 & 455 & 1300 \\
\hline & Water & 206 & 823 & 450 & 1270 \\
\hline \multirow[t]{4}{*}{ Peat } & pH 3.6 & 338 & 973 & 665 & 1510 \\
\hline & pH 5.4 & 298 & 925 & 645 & 1445 \\
\hline & Salt & 393 & 1030 & 605 & 1445 \\
\hline & Water & 408 & 1083 & 590 & 1435 \\
\hline
\end{tabular}

the peat leachates than in the sand leachates (Table 4). Usually, the absorbance was less in $+5^{\circ} \mathrm{C}$ than in $+20^{\circ} \mathrm{C}$ and the values decreased during the experiment. The absorbances increased in the same order as the pH-value increased.

The cumulative amounts of metals in the leachates are indicated in the Figures. In the leachates from the sand columns, there was a positive correlation between the cadmium content and the absorbance after the pH 3.6 and 5.4 treatments. The salt-treated leachates contained the least humus but carried the most cadmium. No correlation between the absorbance and cadmium content was observed in the leachates from the peat columns. In the lower temperature, there was a positive correlation between cadmium and mercury in the sand column leachates (pH 3.6 and 5.4 and water).

After treatment with the salt solution there was a significant positive correlation between mercury and absorbance in both temperatures in the peat column but not in the sand column leachates. In the lower temperature, there was a negative correlation between mercury and $\mathrm{pH}$ in leachates after $\mathrm{pH} 5.6$ treatment.

\section{Cadimum in Soil Profiles}

Cadmium was normally so strongly bound to the peat in the lysimeters that cadmium was detected in the leachates only after treatment with the salt solution (Figure 1). As a result of a technical hitch
Table 3. pH-values of the leachates after 24 and 73 days

\begin{tabular}{llllll}
\hline & & \multicolumn{2}{l}{$+20^{\circ} \mathrm{C}$} & & $+5{ }^{\circ} \mathrm{C}$ \\
Days & & & & \\
\cline { 3 - 6 } Treatment & & 24 & 73 & 24 & 73 \\
\hline Sand & pH 3.6 & 5.4 & 5.5 & 5.0 & 5.5 \\
& pH 5.4 & 5.7 & 6.5 & 5.3 & 5.6 \\
& Salt & 4.3 & 4.6 & 4.3 & 4.4 \\
& Water & 5.3 & 6.0 & 5.2 & 5.6 \\
\multirow{4}{*}{ Peat } & pH 3.6 & 4.3 & 4.5 & 4.2 & 4.5 \\
& pH 5.4 & 5.7 & 6.5 & 5.3 & 5.6 \\
& Salt & 3.2 & 3.2 & 3.1 & 3.1 \\
& Water & 4.5 & 4.7 & 4.4 & 4.9 \\
\hline
\end{tabular}

Table 4. Color (absorbance at $270 \mathrm{~nm}$ ) of the leachates after 24 and 73 days

\begin{tabular}{llllll}
\hline & & $\begin{array}{l}+20^{\circ} \mathrm{C} \\
\text { Days }\end{array}$ & & $+5{ }^{\circ} \mathrm{C}$ & \\
\cline { 3 - 6 } Treatment & & 24 & 73 & 24 & 73 \\
\hline Sand & pH 3.6 & 0.17 & 0.04 & 0.14 & 0.09 \\
& pH 5.4 & 0.31 & 0.22 & 0.30 & 0.15 \\
& Salt & 0.10 & 0.05 & 0.08 & 0.02 \\
& Water & 0.21 & 0.14 & 0.17 & 0.17 \\
Peat & pH 3.6 & 0.38 & 0.41 & 0.27 & 0.15 \\
& pH 5.4 & 0.52 & 0.44 & 0.25 & 0.25 \\
& Salt & 0.06 & 0.05 & 0.12 & 0.07 \\
& Water & 0.43 & 0.45 & 0.42 & 0.24 \\
\hline
\end{tabular}

some of the cadmium values from $+5^{\circ} \mathrm{C}$ were not reliable and were consequently omitted.

In the sand, cadmium leached deeper than in the peat columns and the salt solution again caused the strongest leaching (Figures 2 and 3). In the lower temperature, the distributions were more irregular and a strong leaching was observed after treatment with the stronger acid rain ( $\mathrm{pH} 3.6)$.

\section{Mercury in Soil Profiles}

Mercury was strongly bound to the surface layer of the peat columns. The differences between different treatments were small in both temperatures (Figures 4 and 5). In the sand, more distinct differences were detected especially at $+5^{\circ} \mathrm{C}$; at this temperature, more mercury was mobilized from the top when using the "North Scandinavian" acid rain than from the columns irrigated with "Central European" rain (Figures 6 and 7).

\section{Discussion}

Under acid conditions, cadmium is one of the most readily soluble heavy metals. The addition of $\mathrm{Na}$ and $\mathrm{Ca}$-ions caused a strong acidification by means 


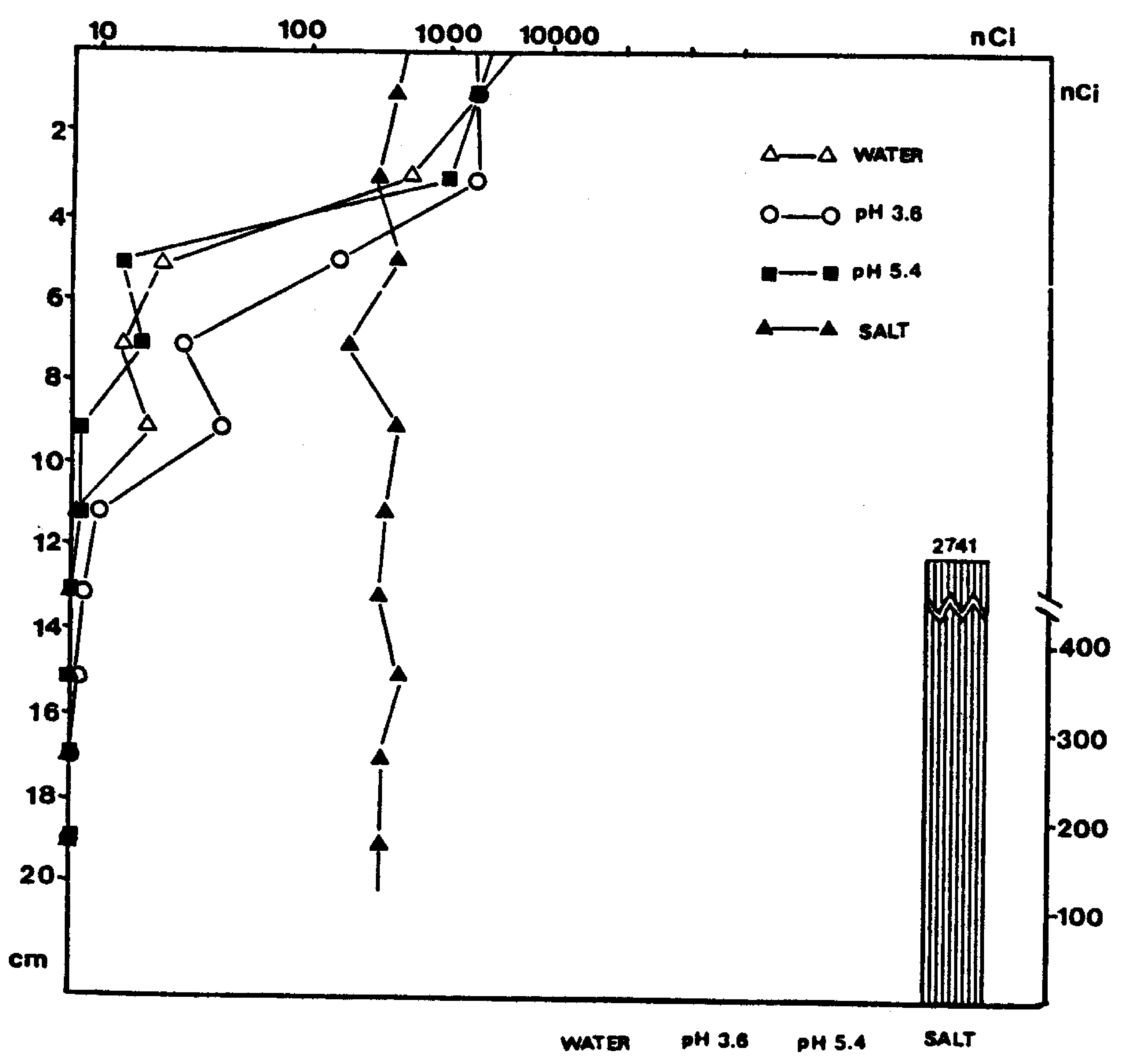

Fig. 1. Distribution of cadmium (as activity, nCi; log scale) in peat profiles after treatment with four different eluents in $+20^{\circ} \mathrm{C}$. The total amounts of $\mathrm{Cd}$ leached out during the experiment are given at the right bottom

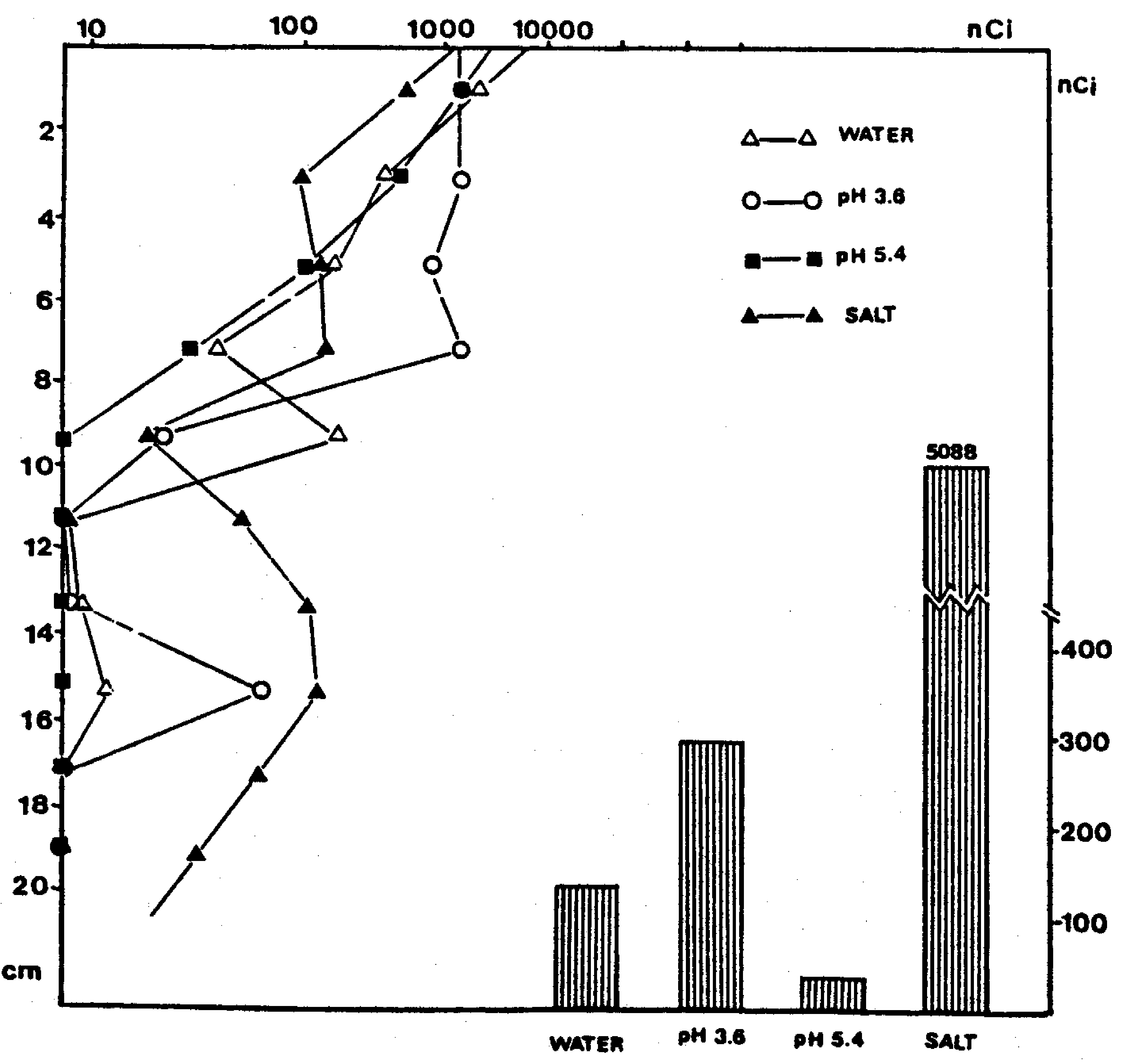

Fig. 2. Distribution of cadmium (as activity, $\mathrm{nCi} ; \log$ scale) in sand profiles after treatment with four different eluents in $+20^{\circ} \mathrm{C}$. The total amounts of Cd leached out during the experiment are given at the right bottom 

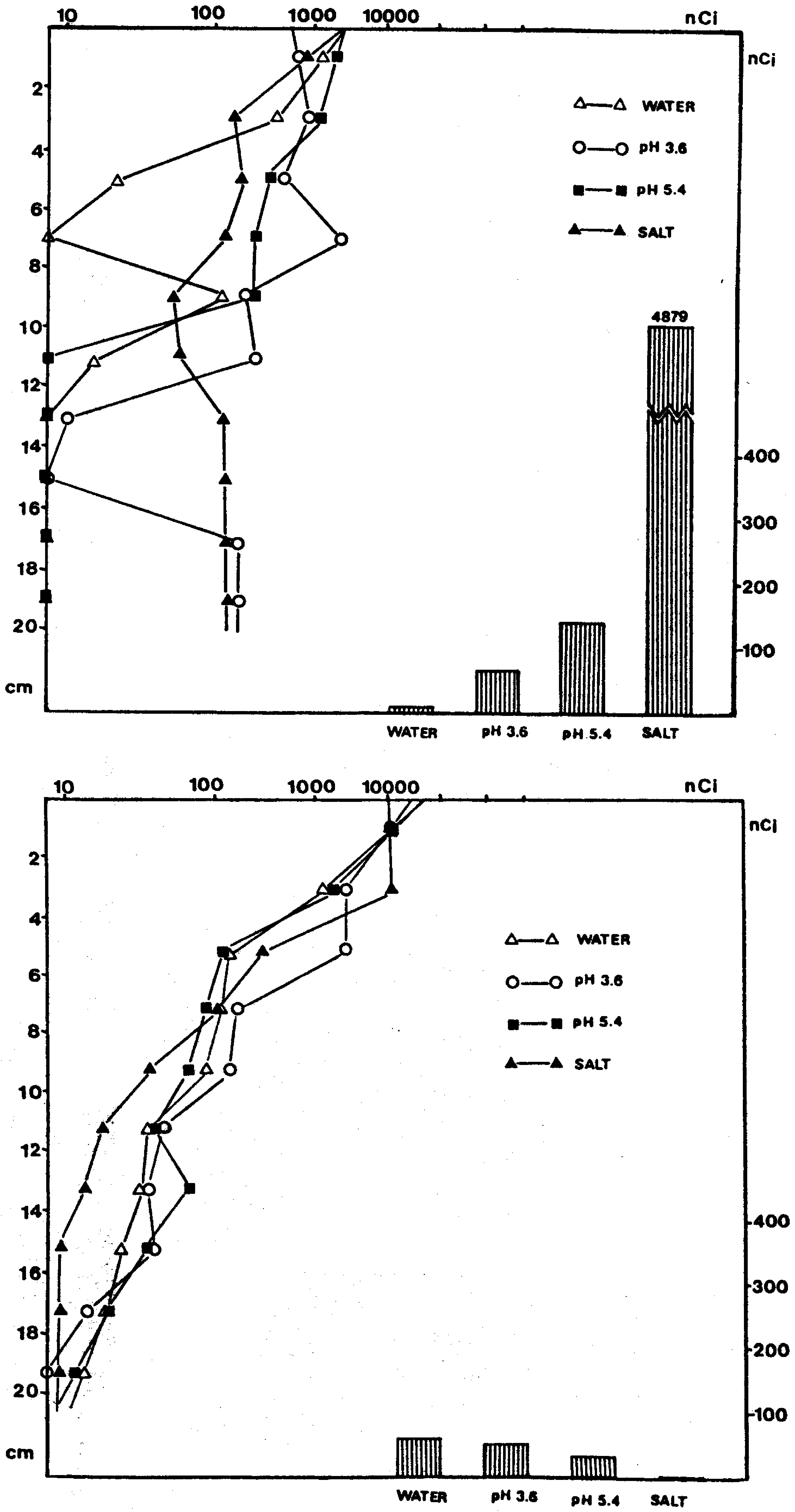

Fig. 3. Distribution of cadmium (as activity, nCi; log scale) in sand profiles after treatment with four different eluents in $+5^{\circ} \mathrm{C}$. The total amounts of $\mathrm{Cd}$ leached out during the experiment are given at the right bottom
F6. 4. Distribution of mercury (as activity, $\mathrm{nCi}$ : log scale) in peat profiles after treatment with four different eluents in $+20^{\circ} \mathrm{C}$. The total amounts of $\mathrm{Hg}_{\mathrm{g}}$ leached out during the experiment are given at the right bottom 


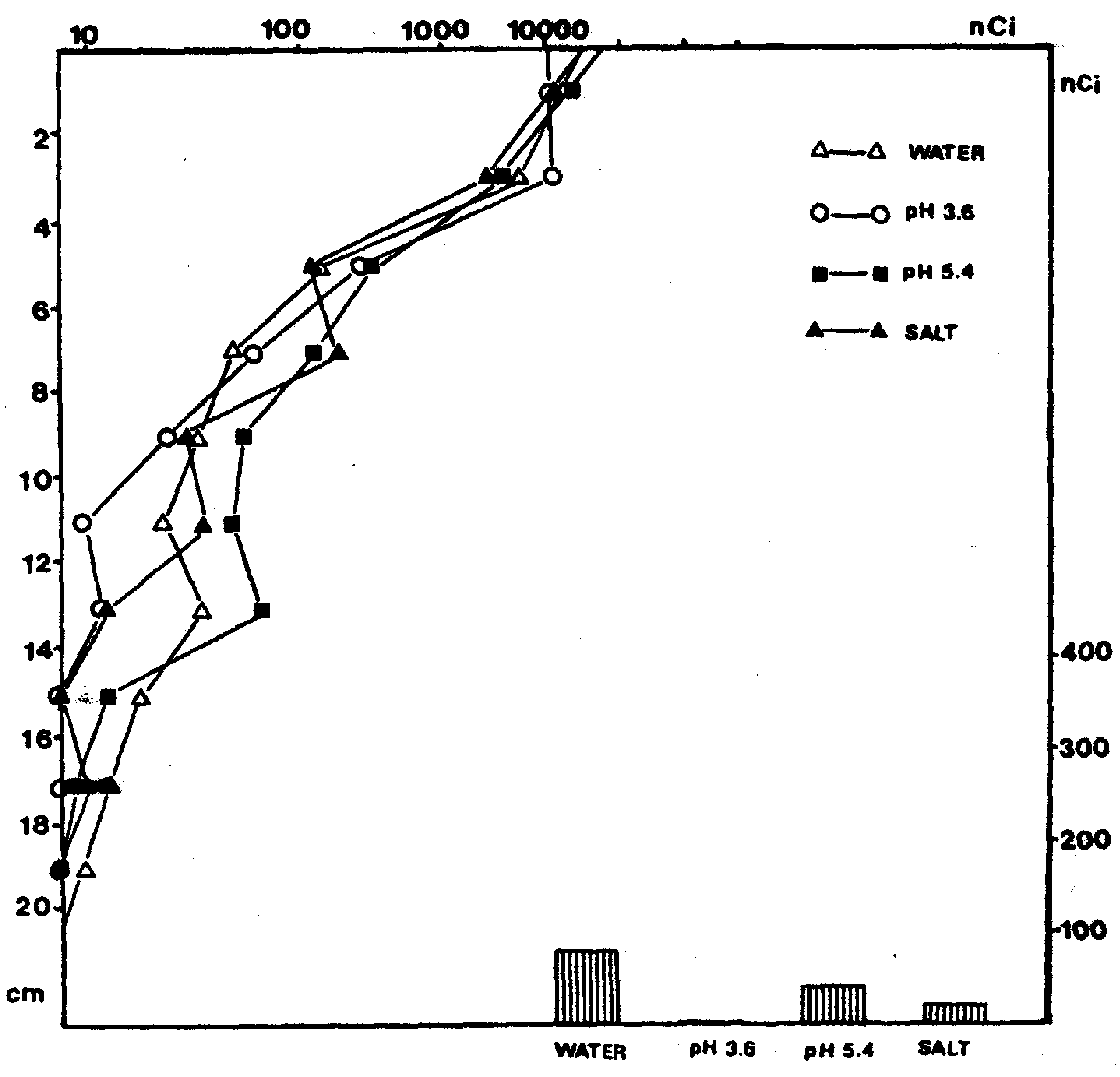

F5. 5. Distribution of mércury (as activity, nCi; log scale) in peat profiles after treatuent with four different eluemas in $+5^{\circ} \mathrm{C}$. The total amounts of $\mathrm{Hg}$ leached out during the experiment are given at the right bottom

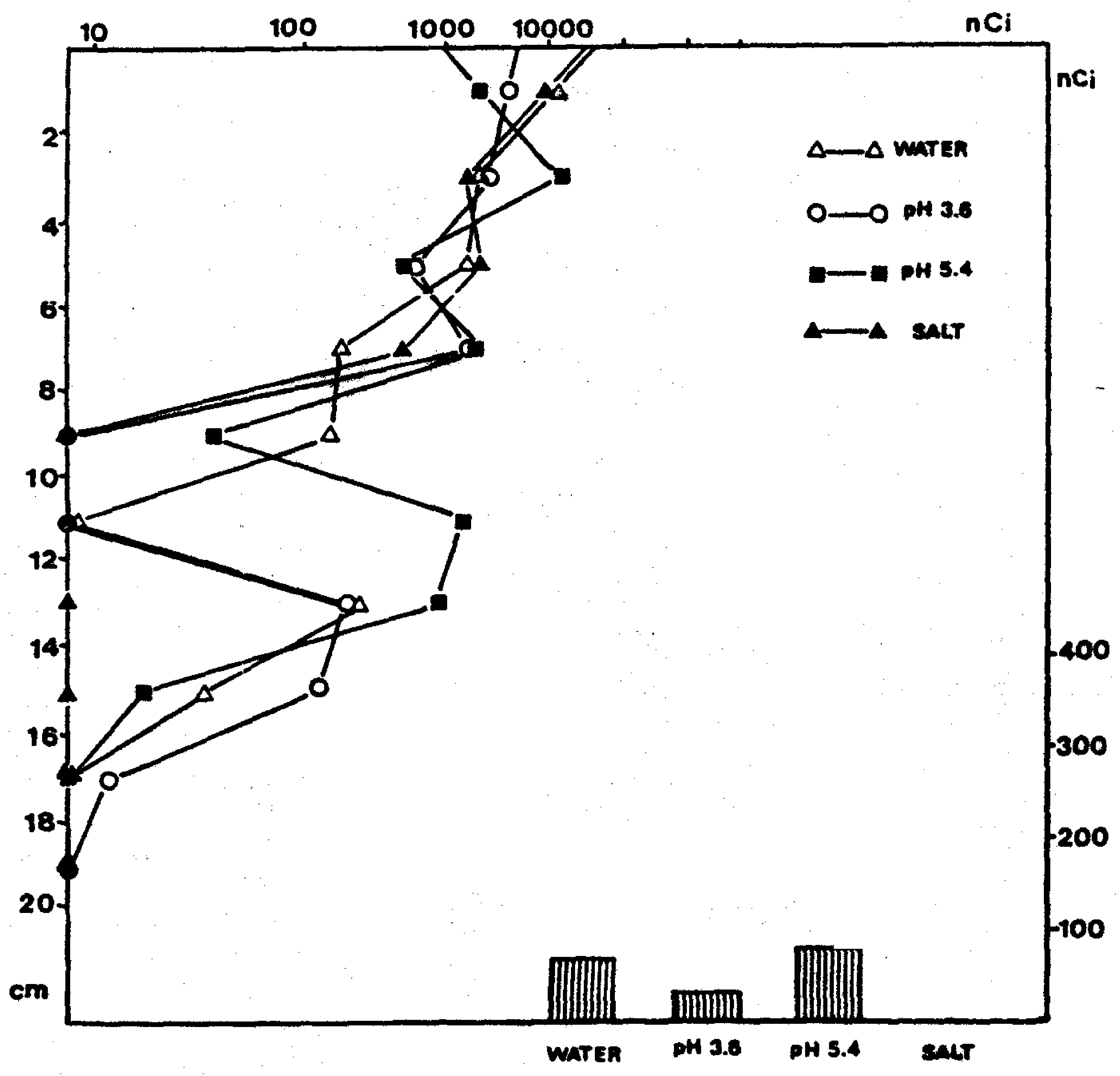

12. 6. Distribution of mercury (as acitivity, nCi; los scale) in sand profiles after treatment with four different eluents in $+20 \mathrm{C}$. The total amounts of $\mathrm{H} g$ leached out during the experiment are given at the right bottom 


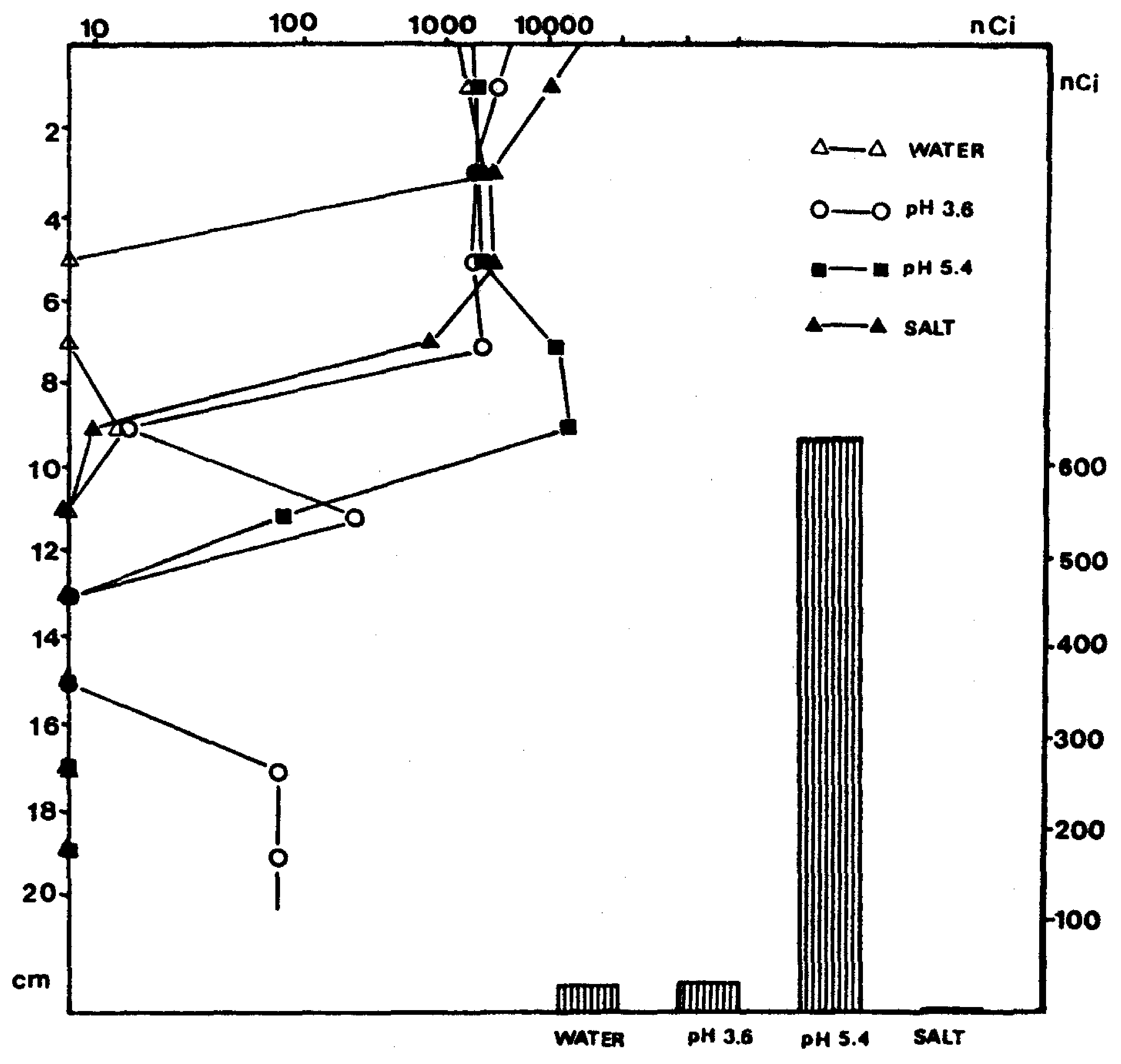

Fig. 7. Distribution of mercury (as activity, nCi; log scale) in sand profiles after treatment with four different eluents in $+5^{\circ} \mathrm{C}$. The total amounts of $\mathrm{Hg}$ leached out during the experiment are given at the right bottom of cation exchange. The solubility of cadmium increases with acidification, beginning at pH 6 (Brümmer \& Herms 1983). Elliott et al. (1986) observed a strong sorption of cadmium with increasing amounts of organic matter and assumed that a reduced mobility should occur, especially under acidic conditions, where the formation of soluble metal complexes is limited. Slavek and Pickering (1981) observed an increased sorption of cadmium after addition of fulvic acid to clay suspensions. Our results indicate that $\mathrm{pH}$ is more important for the leaching of cadmium than the content of organic matter. Herms and Brümmer (1980) also considered the mobilizing effect of organic substances small. The mobility has also been shown to be strongly dependent upon microbial activity. This microbial mobilization is considerably greater under anaerobic than aerobic conditions (Chanmugathas and Bollag 1987).

The importance of humic matter for the sorption of mercury is well known (Strohal and Huljev 1971; Lodenius et al. 1983, 1987a). Mercury may be bound even to pure quartz sand, but in this case mercury is easily removed by acid rain (Lodenius et al. 1987b). Mercury is especially bound to large molecular humic compounds (Lodenius and Seppänen 1984). The humic matter is obviously the principal carrier in the transport of mercury from terrestrial to aquatic ecosystems and the bioaccumulation in aquatic food-chains (Surma-Aho et al. 1986).

While there was no clear effect of temperature on the leaching of cadmium, a significantly stronger leaching of mercury was found at $+5^{\circ}$ than at room temperature. This temperature effect was observed earlier in a sandy soil (Lodenius et al. 19876). The reasons for this phenomenon are not known.

Acknowledgments. We are indebted to Esa Tulisalo and Antti Uusi-Rauva for technical assistance and the Academy of Finland for financial support.

\section{References}

Brummer G. Herms $U$ (1983) Influence of soil reaction and organic matter on the solubility of heavy metals in soils. In Ulrich B, Pankrath J (eds) Effects of accumulation of air 
pollutants in forest ecosystems. Reidel Publ, Dordrecht, Boston, London, pp 233-243

Chanmugathas P, Bollag J-M (1987) Microbial mobilization of cadmium in soil under aerobic and anaerobic conditions. $J$ Environ Qual 16:161-167

Elliott HA, Liberati MR, Huang CP (1986) Competitive adsorption of heavy metals by soils. J Environ Qual 15:214-219

Herms U, Brümmer G (1980) Einfluss der Bodenreaktion auf Löslighkeit und tolerierbare Gesamthalte an Nickel, Kupfer, Zink, Cadmium und Blei in Boden und kompostierten Siedlungsabfallen. Landwirtsch Forsch 33:408-423

Lodenius M, Seppănen A (1984) Kvicksilvrets bindning till humus $i$ vatten. (Summary: Binding of mercury to aquatic humus). Vatten 40:302-307

Lodenius M, Seppänen A, Uusi-Rauva A (1983) Sorption and mobilization of mercury in peat soil. Chemosphere 12:15751581
Lodenius M, Seppinen A, Autio S (1987a) Leaching of mercury from peat soil. Chemosphere 16:1215-1220

(1987b) Sorption of mercury in soils with different humus content. Bull Environ Contam Toxicol 39:593-600

Slavek J, Pickering WF (1981) The effect of pH on the retention of $\mathrm{Cu}, \mathrm{Pb}, \mathrm{Cd}$, and $\mathrm{Zn}$ by clay-fulvic acid mixtures. Water Air Soil Pollut 16:209-221

Strohal P, Huljev D (1971) Investigations on mercury pollutant interaction with humic acid by means of radiotracers. Proc Symp Nucl Techn Environ Pollut (IAEA): 439-466

Surma-Aho K, Pansivirta J, Rekolainen S, Verta M (1986) Oranic and inorganic mencury in the food chain of some lakes and reservoirs in Finland. Nat Bd Waters, Finland, Publ Water Res Inst 65:59-71

Manuscript received February 24, 1988. 